Please do not remove this page

RMIT

UNIVERSITY

\title{
Educating for evolving consciousness: voicing the emergency for love, life and wisdom
}

Gidley, Jennifer

https://researchrepository.rmit.edu.au/esploro/outputs/9921863618301341/filesAndLinks?institution=61RMIT_INST\&index=null

Gidley, J. (2009). Educating for evolving consciousness: voicing the emergency for love, life and wisdom. In International Handbook of Education for Spirituality, Care and Wellbeing (pp. 553-561). Springer.

https://researchrepository.rmit.edu.au/discovery/fulldisplay/alma9921863618301341/61RMIT_INST:Resea rchRepository

Repository homepage: https://researchrepository.rmit.edu.au

(c) Springer 2009

Downloaded On 2023/04/26 21:54:49 +1000

Please do not remove this page 


\title{
EDUCATING FOR EVOLVING CONSCIOUSNESS: VOICING THE EMERGENC-Y FOR LOVE, LIFE AND WISDOM
}

\author{
Dr. Jennifer M. Gidley \\ Research Fellow \\ Global Cities Research Institute \\ RMIT University \\ Melbourne, Australia 3000
}

\begin{abstract}
This paper takes as its starting point the notion that human consciousness is evolving beyond the boundaries of formal, reductionist modes of thinking and beginning to open to postformal, integral and planetary consciousness. It explores the theoretical relationships between several themes arising from the evolution of consciousness discourse and a diversity of postformal educational discourses. Four core pedagogical values emerge from the intersection between these two clusters: love, life, wisdom and voice. These core values are elucidated theoretically in relation to philosophies of education, and practically through examples from the art of education. They are offered as pedagogical seeds for evolving consciousness through education in the $21^{\text {st }}$ century.
\end{abstract}

Keywords

Holistic, Integral, Life, Love, Pedagogy, Planetary, Postformal, Spirituality, Wisdom, Voice

Author Keywords

Kieran Egan, Tobin Hart, Joe Kincheloe, Maggie MacLure, Ron Miller, Jan Sinnott, Douglas Sloan, Robert Sternberg, Rudolf Steiner, Ken Wilber 
From Planetary Crisis to Planetary Consciousness

All of the leading holistic thinkers identify the crisis of our time as an epistemological crisis. We are not arguing against technology as such, or against capitalism in itself. We are saying that underneath our political, social, and economic arrangements, the way modern culture defines and understands reality itself is faulty (Miller, 2006, para. 6)

I fully concur with educational philosopher, Ron Miller, that the crisis of our times is an epistemological crisis. The monoculture that is increasingly dominating the planet is based on a modernist worldview underpinned by scientific materialism (Whitehead, 1925). It utilises formal thinking to express its associated epistemology of reductionism. ${ }^{1}$ Its method of enculturation of young people into its worldview is mass formal education based on an Industrial Era factorymodel of schooling (Gidley, 2001). Over the last decade the reductionist, scientistic, mode of formal thinking has been intensified across the social sciences by a neo-fundamentalist, economic-rationalist backlash against the flourishing of qualitative research (Coryn, Schröter, \& Scriven, 2005; Denzin, 2005). This has impacted on education particularly through the dominance of the audit culture with its obsessive quantitative accountability practices and its agenda of a narrowly-defined science of education (MacLure, 2006b). Contemporary educational research - at least in the UK, the USA and Australia - is increasingly constrained by this neofundamentalist research agenda. My research points to paths beyond these constraints to emergent, postformal philosophies and arts of education that support the evolution of consciousness.

The history of research into the evolution of consciousness and the significant contributions of Rudolf Steiner, Jean Gebser and Ken Wilber to the identification and development of new stage/s or movements of consciousness have been discussed extensively elsewhere (Gidley, 2006, 2007a, 2007b). These researchers claim that human consciousness is evolving beyond the formal, intellectual, abstract mode toward a postformal, integral, more spiritual $^{2}$ mode. Steiner (1930/1983) called it consciousness/spiritual soul, Gebser (1949/1985) called it integral-aperspectival, and Wilber (2000a, 2000b) calls it vision-logic or integral.

Current research also indicates that the monological mode of formal thinking is obsolete, and is not capable of taking us through the current planetary crisis. Many contemporary thinkers echo Einstein's ${ }^{3}$ thoughts of a century ago that "The significant problems we have cannot be solved at the same level of thinking with which we created them." I have identified three major research threads that point to the emergence of new ways of thinking suggestive of what Gebser (1949/1985) referred to as a new structure of consciousness. These threads are principally represented by the terms postformal, integral and planetary.

Adult developmental psychologists have been providing empirical and analytic evidence for decades for at least one, and potentially several, stage/s of postformal reasoning beyond Piaget's formal operations (Commons \& Richards, 2002; Kramer, 1983; Sinnott, 1998). Secondly, there are a range of integral theorists whose work provides a counter-balance to reductionism by engaging postformal epistemologies such as transdisciplinarity, complexity, systems theory and holism $^{4}$ (Braud, 1998; Combs, 2002; Goerner, 2000; Hampson, 2007; László, 2007; Ray, 1996; Wilber, 2001, 2004). Thirdly, contemporary researchers focused on cultural evolution and/or our planetary crisis indicate the need for planetary consciousness (Earley, 1997; Gangadean, 2006; Montuori, 1999; Morin \& Kern, 1999). Philosopher Edgar Morin is a 
powerful proponent of the need for complex, ecological and planetary thinking in our times which he calls the Planetary Era (Morin, 2001; Morin \& Kern, 1999).

Many of the postformal, integral/holistic and planetary researchers point to a growing spiritual awareness. Neurosurgeon and cognitive scientist, Karl Pribram, who developed holonomic brain theory with quantum physicist, David Bohm (1980) also makes this link.

The type of holism revealed by holography is kin to the holism of the holy, the healthy. The discovery of holography is thus a most important occurrence: For the first time in centuries scientific practice and theory have brought science and the spiritual disciplines into congruence. (Pribram, 2006, p. 44)

Postformal features identified by the adult developmental psychologists include: complexity, construct-awareness, ${ }^{5}$ contextualisation, creativity, dialectics, dialogue, holism, imagination, paradox, pluralism, reflexivity, spirituality, values and wisdom (Arlin, 1999; Cartwright, 2001; Commons, Trudeau, Stein, Richards, \& Krause, 1998; Cook-Greuter, 2000; Falcone, 2000; Kegan, 1994; Kohlberg, 1990; Kramer, 1983; Labouvie-Vief, 1992; Riegel, 1973; Sinnott, 1998, 2005). I am using these postformal features as identifiers of what I refer to as postformal educational approaches in contrast with formal — sometimes called mainstreameducation. I am not denying that there are different philosophical streams and methods within formal education. Rather, I am suggesting there is a tacit template that most contemporary schools are based on that comes from the industrial era, because that is the main genealogy of mass school ${ }^{6}$ education (Dator, 2000).

The postformal, integral/holistic and global/planetary orientations are not mutually exclusive categories but intimately interconnected. I have coined the conjoined term postformalintegral-planetary consciousnesss ${ }^{7}$ to cohere threads in the evolution of consciousness research (Gidley, 2007b). The focus of this paper is the vital significance of this research for education.

\section{From Formal Schools to Postformal-integral-planetary Pedagogies}

My research has indicated that the initial impulse for Humboldt's implementation of mass public education in Germany was influenced by his collaboration with German idealists and romantics such as Goethe, Hegel, Schelling and Novalis whose work was inspired by the notion of the evolution of consciousness. This was carried forward particularly through Schiller's aesthetic educational principles, while Herbart's pedagogical system influenced the practice. However, after the deaths of these leading German philosophers, by the middle of the 19th century the idealist-romantic educational project was largely hijacked by the gradual influence of the British Industrial Revolution, so that schools increasingly became training grounds to provide fodder for the factories. This factory model of school education was picked up in the USA. I am not denying that there are different philosophical streams and methods within formal education. Rather, I am suggesting there is a tacit industrial era template that most contemporary educational institutions are based on that has been the main influence on mass education for at least one hundred and fifty years (Dator, 2000).

The modernist phase of formal school education is trapped within industrial, mechanistic and technicist metaphors. Its entrenchment hinders the emergence of new consciousness. Formal thinking and educational practices limit cultivation of other ways of knowing in several ways. 
- They educate for the past, for forms of consciousness that are becoming outmoded and are no longer adequate for the complexity of $21^{\text {st }}$ century postmodern life on an ailing planet (Gidley, 2007b; Giroux, 1999/2005; Miller, 1993; Morin, 2001; Orr, 1994);

- They privilege one way of knowing (cognitive) over significant others, such as aesthetic, affective, contemplative, imaginative, intuitive, kinaesthetic, musical, inter- and intrapersonal and participatory (Egan, 1997; Gardner, 1996; Hart, 1998; Kessler, 2000a; Nava, 2001; Nielson, 2006; Noddings, 2003; Rose \& Kincheloe, 2003; Zajonc, 2006);

- They are grounded in binary logic, privileging the hegemonic side of any pair of binaries, eg science over literature, maths over art, intellect over emotion, materialistic over spiritual, order over creativity (Chater, 2006; de Souza, 2006; Finser, 2001; Glazer, 1994; Johnson, 2005; Pridmore, 2004; Subbiondo, 2005);

- They privilege and encourage the transmission of deadening, stale concepts rather than evoking a process of awakening mobile, living thinking (Deleuze \& Conley, 1992; St. Pierre, 2004; Whitehead, 1916/1967)

- They support the current regression to scientistic, neo-fundamentalist, educational research styles, linked to positivist performativity and the audit culture - over complex, emergent, qualitative, creative inquiry (Denzin, 2005; Kincheloe \& Berry, 2004; Lyotard, 2004; MacLure, 2006b; Montuori, 2006);

- They privilege the economic rationalist business model of education as commodity over all other orientations (Giroux, 2001; Morin \& Kern, 1999; Steinberg \& Kincheloe, 2004);

- They fragment and compartmentalise knowledge in ways that many young people find meaningless (Eckersley, Cahill, Wierenga, \& Wyn, 2007; Gidley, 2005; Miller, 1993).

By contrast, early $20^{\text {th }}$ century educational contributions of Steiner (1909/1965) and Montessori (1916/1964) in Europe, followed by Sri Aurobindo ${ }^{8}$ in India, foreshadowed the educational possibilities that might arise once the implications of the evolution of consciousness are acknowledged. A driving force underlying their educational approaches was a notion of the evolution of cosmos and consciousness that embraces more spiritual perspectives. Several contemporary educators have undertaken comparative studies of their approaches (Coulter, 1991; Gidley, 2007a; Marshak, 1997; Miller, 1990).

A plurality of educational alternatives to the factory model has arisen since then and has been discussed elsewhere (Gidley, 2007a, 2008). What I am clustering as postformal alternatives include aesthetic, creative, imaginative, integral, holistic and transformative approaches; critical, postmodern and poststructuralist pedagogies; and approaches which foreground complexity, ecology, futures studies, spirituality and wisdom. The following section distils core values from the plethora of postformal educational possibilities. 
Table 28.1: Socio-Cultural, Political and Educational Phases ${ }^{1}$

\begin{tabular}{|l|l|l|l|}
\hline & $\begin{array}{l}\text { Prehistory to } \mathbf{1 8}^{\text {th }} \\
\text { Century }\end{array}$ & $\begin{array}{l}\mathbf{1 8}^{\text {th }} \text { to } \mathbf{2 0}^{\text {th }} \\
\text { Century }\end{array}$ & $\begin{array}{l}\mathbf{2 0}^{\text {th }} \text { to } 21^{\text {st }} \text { Century and } \\
\text { Beyond }\end{array}$ \\
\hline $\begin{array}{l}\text { Socio-Cultural } \\
\text { Phases }\end{array}$ & Pre-modern & Modern & Post-modern \\
\hline $\begin{array}{l}\text { Political } \\
\text { Phases }\end{array}$ & City-states & Nation-states & Global-planetary \\
$\begin{array}{l}\text { Education } \\
\text { Phases }\end{array}$ & $\begin{array}{l}\text { Informal family/tribal } \\
\text { enculturation, } \\
\text { or elite tutoring }\end{array}$ & $\begin{array}{l}\text { Formal schooling, } \\
\text { mass education, } \\
\text { factory-model }\end{array}$ & $\begin{array}{l}\text { Pluralism of postformal } \\
\text { pedagogies, integral, } \\
\text { planetary sensibility }\end{array}$ \\
\hline
\end{tabular}

I propose that education - at least in much of the Anglophone ${ }^{9}$ world — is in a transition from formal to postformal, somewhat lagging behind other socio-cultural shifts arising from postmodern impulses (see Table 1). This simple theoretical model is not intended to suggest that there has been a unilinear, or unidimensional, development of culture, politics, consciousness or education. The actual phenomena are more complex, multi-dimensional and recursive.

\section{Linking Evolution of Consciousness Themes with Postformal Educational Approaches}

The primary crisis on the planet now is a crisis of consciousness, and our global wisdom suggests that humanity is in a painful transformation toward a more healthful integral technology of mind that ushers in a new sustainable global civilization wherein the whole human family may flourish together on our sacred planet. (Gangadean, 2006)

Recent research into the evolution of consciousness has organised the literature into themes (Gidley, 2007a, 2007b). This paper explores the theoretical relationships between four themes that emerged from the evolution of consciousness discourse and the various discourses on emergent postformal ${ }^{10}$ educational approaches. Although there is considerable overlap and interpenetration between and among the evolutionary themes and the postformal educational approaches, the latter have been clustered under the evolution of consciousness theme that they appear to most strongly support. Consequently, I would like this clustering to be viewed as a type of delicate theorising ${ }^{11}$ that has arisen from a postformal research process involving hermeneutic interpretation, not empirical analysis. This postformal clustering into themes is to be distinguished from formal categorisation into discrete territories as one might see in formal analysis. My attempts to cohere this diverse literature are a step in formulating a complex educational philosophy that supports the evolution of consciousness.

\footnotetext{
${ }^{1}$ This table refers primarily to the situation in the so-called developed world. The situation is far more diverse and complex in traditional, and non Western-European-based cultures.
} 
Discourses that Include Notions of Conscious, Active Spiritual Development

This theme includes religious, and particularly post-traditional and postmodern spiritual approaches that promote active spiritual development (Bouma, 2006; Huston, 2007; Tacey, 2003; Wilber, 2006). While the term spiritual is still controversial in continental philosophy (Benedikter, 2005) it is arising in the higher education landscape in the USA (Scott, 2000; Subbiondo, 2005) through the emergence of contemplative studies programs ${ }^{12}$ and active science/spirituality dialogues (Hefner, 1998; Russell, 2002). I propose that evolutionary spiritual approaches are supported by educational styles that emphasise care, contemplation, empathy love and reverence. Such approaches include the spirituality in education movement (de Souza, 2006; Erricker, Ota, \& Erricker, 2001; Glazer, 1994; G. Woods, O'Neill, \& Woods, 1997), holistic education, and transformative education that engages contemplative pedagogies (Altobello, 2007; Brady, 2007). I cohere these related clusters of evolutionary and educational research under the core value of pedagogical love.

\section{Discourses that Resist the Static, Deadening Nature of Formal Thinking and Enact More Mobile, Life-Enhancing, Postformal Thinking}

This new thinking is reflected in organic, process-oriented, postmodern and poststructuralist philosophies which emerged last century (Bergson, 1911/1944; Derrida, 2001; Whitehead, 1929/1985). This paralleled the emergence of new science theories such as Einstein's theory of relativity, quantum physics and systems science. The changing consciousness is particularly notable in the shift from simple mechanistic metaphors to life-enhancing, organic metaphors in the new, post-classical, biology theories of chaos, complexity, self-organisation and emergence (Goodenough \& Deacon, 2006; Jantsch, 1980; László, 2006; Varela, Thompson, \& Rosch, 1993). I propose that several postformal educational approaches support this movement from static concepts to living thinking. In particular, imagination is a primary method of bringing concepts to life. Life and its metaphors are also emphasised in pedagogies grounded in ecology, futures thinking, sustainability, complexity and aesthetics. Such approaches nurture vitality and wellbeing. I cohere them under the core value of pedagogical life.

\section{Discourses that Identify Increasing Creativity, Complexity and Multi-Perspectivality as Movements Towards Wisdom}

These include two sub-streams: cultural evolutionary (phylogenetic) and individual developmental (ontogenetic). Both streams explicitly identify the emergence of new stage/s, structures or movements of consciousness. Adult developmental psychologists indicate that postformal features particularly linked to wisdom are creativity, multiperspectivality and spirituality. The interaction between these features and complexity, paradox and dialectics is not hard to envisage. The contemporary cultural evolution literature -much of which arises from the integral theoretic narratives - often also stresses the planetary dimension of consciousness as a feature of wisdom. There are specific educational theories addressed to the cultivation of wisdom (Falcone, 2000; Hart, 2001a, 2001b; Sternberg, 2001). However, other postformal approaches that are oriented towards creativity and complexity also facilitate the cultivation of wisdom. In 
addition, education in spirituality and aesthetics are also linked with wisdom in the literature. I cohere these threads under the core value of pedagogical wisdom.

\section{Discourses that Integrate by Crossing Linguistic and Paradigmatic Barriers}

There is an evolutionary academic and educational movement beyond fragmentation and disciplinary isolationism and towards more integration - through integral and holistic theories,

inter- and transdisciplinarity, and dialogic ${ }^{13}$ approaches. A challenge that has emerged from the inter- and transdisciplinary literature is the difficulty in communicating across different disciplines, epistemologies and paradigms (Eckersley, Wierenga, \& Wyn, 2006; Grigg, Johnston, \& Milson, 2003; Nicolescu, 2002). An evolutionary philosophy of education that can overcome this challenge requires tremendous sensitivity to linguistic, cultural and paradigmatic contexts. An important insight of French postmodern/poststructuralist philosophy is awareness of context in terms of how we language the world. Arguably, the linguistic turn in philosophy has not yet significantly influenced formal education. I propose that this integrative capacity of language reflexivity is supported by postmodern/poststructuralist, aesthetic/poetic and critical/postcolonial pedagogies. I cohere these threads under the core value of pedagogical voice.

\section{Postformal-integral-planetary Pedagogies for Evolving Consciousness}

And the strength of the thread does not reside in the fact that some fibre runs through its whole length, but in the overlapping of many fibres. ${ }^{14}$ (Wittgenstein, 1968, p. 32)

These complexly interwoven theoretical issues contribute to the formulation of an evolutionary philosophy of education based on a multitude of fibres of postformal, philosophical, psychological and educational theory. I also include numerous rich, creative examples from my - and others' - teaching experience in the evolving art of education. This paper seeks to reflect the pluralism among the postformal educational approaches that nurture one or more of the qualities that support the evolution of consciousness. My initial endeavour to cohere the diverse evolutionary and educational discourses is an educational philosophy that reflects unity in diversity. The fibres converge into threads and the threads are woven into what I call postformal-integral-planetary pedagogies. (See Figure 1)

At the intersections between the evolutionary and postformal educational discourses I have identified the following four core values:

- Pedagogical Love

- Pedagogical Life

- Pedagogical Wisdom

- Pedagogical Voice 
Figure 28.1: Towards postformal-integral-planetary pedagogies: an educational philosophy nurturing evolution of consciousness

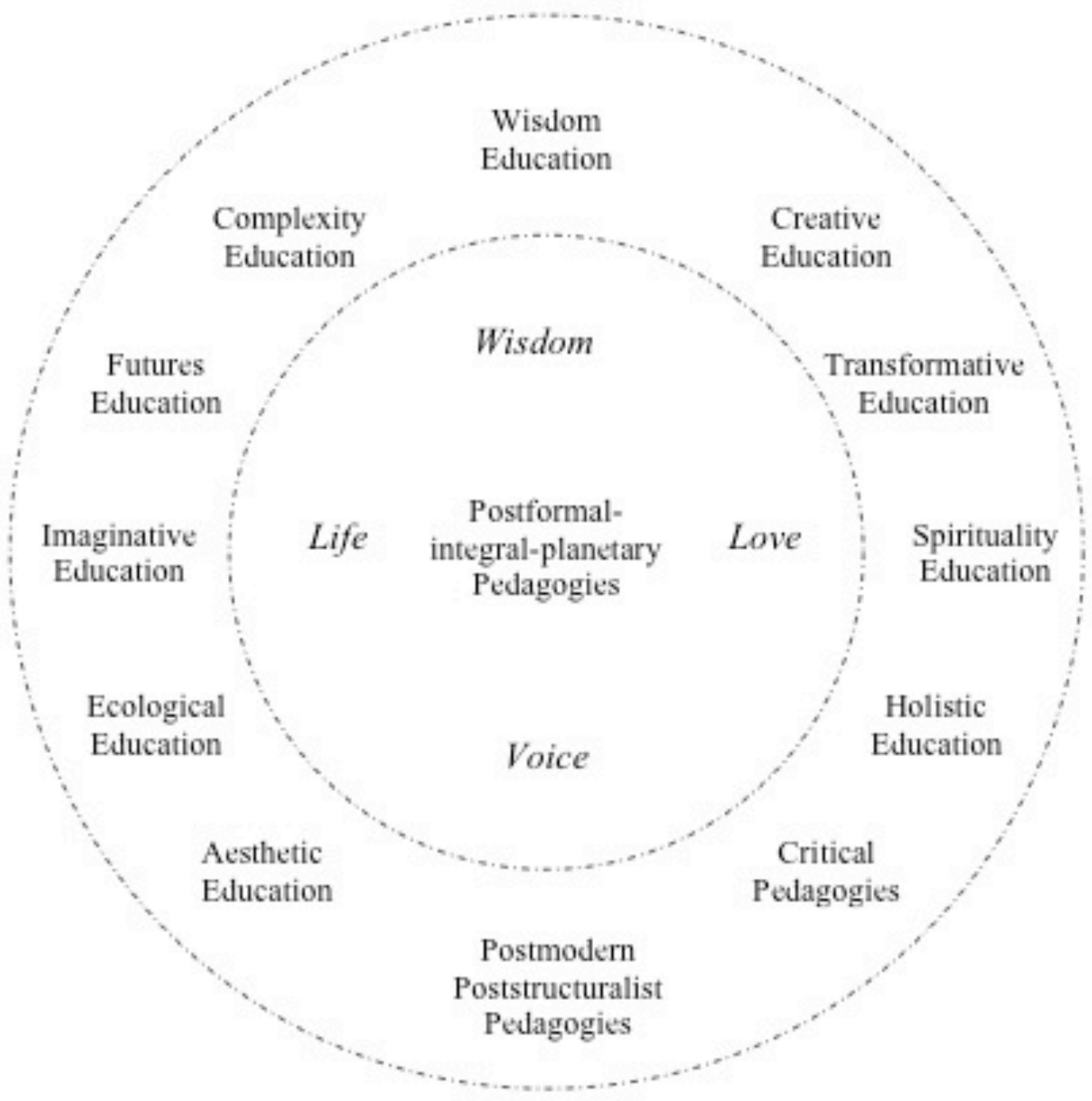

The following four sections each begin with philosophical perspectives and then continue with examples from the art of education. The philosophical/conceptual component of each section points to historical and theoretical links with the evolution of consciousness discourses, while the more practical component integrates diverse pedagogical experiences. Since these core values are emerging from the complex, dialectical, postformal, integral mindset, they are not mutually exclusive but complexly interconnected. I individualise each to fully honour its particularity and orient readers (even postformal ones) who have their favourite emphasis. 


\section{Pedagogical Love}

Philosophical Perspectives: The Heart of a Teacher's Gaze

The word 'love' is rarely mentioned in educational circles. The word seems out of place in a world of outcomes, accountability, and standardised tests. (J. Miller, P., 2000, p. 31)

And yet love is clearly central to spiritual development in most religious and spiritual traditions. In Christianity, Buddhism and Islam, Love and/or Compassion are central indications of Divinity, Allah, Christ- or Buddha-nature. Steiner gave lectures in 1909 where he explicitly named love and devotion - which he referred to as the two components of reverence-as educative forces for developing the next stage of consciousness.

Love and devotion are...the best educators of the soul in its advances from the Intellectual Soul to the Consciousness Soul...But this reverence must be led and guided from a standpoint which never shuts out the light of thought. (Steiner, 1930/1983, pp. 6162)

Alfred North Whitehead (1916/1967), writing a few years after Steiner, affirmed the significance of reverence in his philosophy of education.

The essence of education is... religious [it]...inculcates duty and reverence... And the foundation of reverence is this perception, that the present holds within itself the complete sum of existence, backwards and forward, that whole amplitude, which is eternity. (p. 10)

Whitehead's words are echoed by Gebser's (1949/1985) integral consciousness: “encompassing all time and embracing both man's distant past and his approaching future as a living present" (p. 6).

Several holistic educators speak of love and reverence as touchstones for wisdom (Hart, 2001b; J. Miller, P., 2000; R. Miller, 2000). Developmental psychologists explore wisdom as a feature of postformal thinking (Arlin, 1999; Sinnott, 1994; Sternberg, 2001). Already we are immersed in the complexly interwoven relationship between love and wisdom.

If love and reverence are so significant in the spiritually oriented evolutionary discourses, then we might ask: Why is the word love so out of place in educational circles?

British educationist, Maggie MacLure (2006c) unpacks the trend to privilege scientific, quantifiable words, such as: objectives, outcomes, standards, high-stakes testing, competition, performance and accountability. She links this to "deep-seated fears and anxieties about language and desire to control it." She sees this resistance to the textuality, complexity and diversity of qualitative research in the "evidence-based" agendas of the "audit culture." In this context, words like love are likely to create ontological panic in educrats. But the litany of mental health issues among young people suggests we may have pushed them too far (Gidley, 2005). Perhaps new spaces need to be opened up for softer terms, such as love, nurture, respect, reverence, awe, wonder, wellbeing, vulnerability, care, tenderness, openness, trust. If national governments - as is the case now in the UK and Australia - are serious about well-being and 
spirituality in education, the reductionism and quantification in language needs to be challenged to support a transition (P. A. Woods \& Woods, 2002). As Gebser (1996) said: "our terminology determines to a certain extent the direction of our thought" (p. 84).

Fortunately, in spite of these challenges, the importance of love in educational settings is being re-emphasised through terms such as "epistemology of love" (Zajonc, 2006); and "pedagogy of universal love" (Nava, 2001). The term pedagogical love has also been used in constructivist educational theory (Hatt, 2005). Other educators refer to aligned notions such as "ethics of care" (Noddings, 2005); "heart of a teacher" (Palmer, 1998); and "deep empathy" (Hart, 2000). Nel Noddings and Parker Palmer both link their notions to teacher integrity.

\section{The Art of Pedagogical Love: Being in Love with Learning and Teaching}

The practical application of these (r)evolutionary ideas seems a far cry from the performance outcomes required by the audit culture. Yet the love of teachers for their children, for the ideas to be conveyed, and for learning itself, can be nurtured and demonstrated in several ways. Firstly, by attending to our own inner self-development and self-care. ${ }^{15}$ Some examples from my own inner work — as self-care-include:

- Study of inspirational teachings and other wisdom literature;

- Artistic classes (voice, movement, painting, drama) to promote flexibility of thought, imagination, inspiration and group spirit;

- Modelling love, by showing care and respect. Children learn most profoundly from what is modeled by the adults closest to them (Marshak, 1997);

- My nightly preparation involved three components: study of the subject material to be introduced; study of its deeper/broader context; contemplative surrender to being guided by creative inspiration. The latter step in the process invariably provided, as if on cue, new creative inspiration that enriched and enlivened my lessons for the following day.

Secondly, I actively nurtured my relationship with the children in the following ways. Some of these may seem obvious but are rarely found in pre-service manuals.

- Getting to know my students by finding time to speak individually to each one, even if briefly, during each day;

- Making authentic eye contact - the beholding of the child with "the teacher's gaze" (Uhrmacher, 1993). Ideally, my gaze held a vision of each child's potential in dialectical relationship with the reality of the moment, lifting their hearts up like flowers to the sun.

- Being fully present, not absent-minded, is important and is referred to in the literature as "teacher presence" (Kessler, 2000a, 2000b; Palmer, 1998);

- Meditative contemplation, regularly, on each individual child, throughout the school year (Steiner, 1982);

- Attention to soul nurture and aesthetic nourishment by creating a beautiful, safe environment, physically, emotionally, psychologically—a "gourmet soul chef" perhaps?

- Long term commitment to children for several years, personalises the learning environment (Eisner, 2000; Marshak, 1997);

- Encouraging partnership and cooperation rather than competition, dominance and bullying (Eisler, 2001; Goerner, 2000); 
- Finally, ecological awareness is enhanced by practising care for plants, small animals and other sentient beings (Orr, 1994).

In retrospect, my most interesting lessons were on topics I had to research as they became warmed through with the love for learning I experienced - an advantage of not using textbooks, ${ }^{16}$ once you overcome the fear of "not enough time." By honouring the particularity of each lesson through individualised presentation modes one often finds the extraordinary in the ordinary.

\section{Pedagogical Life}

\section{Philosophical Perspectives: Imagination as Conceptual Vitality}

A thinking that is fragmenting, detached, and rigid will continue to give us a world that is increasingly broken, alien, and dead. The possibility of a living, harmonious, and meaningful world can only be grasped and realised by a thinking and knowing that are themselves living, whole and engaged." (Sloan, 1983, p. xiii)

With these words educational philosopher Douglas Sloan makes an eloquent conceptual bridge between living, integrative thinking and life itself. The term imagination can be used disparagingly as meaning inferior to reason - or formal thinking — or to depict complex, higherorder forms of thinking. The significant role of imagination in higher-order thinking, despite its long history has been academically marginalised. The dialectical and synthesising nature of imagination was identified in the third century CE in Plotinus's conceptual imagination. Steiner-building on Goethe's creative imagination and Schelling's intellectual imaginationexplicitly linked Imagination with the evolution of consciousness (Steiner, 1905/1981). The relationship between imagination and post-mechanistic, organic metaphors in philosophical thinking has foundations in the vitality of Bergson's élan vital (Fraser, Kember, \& Lury, 2005), Whitehead's process thinking (Gare, 1999), and Deleuze's lines of flight (St. Pierre, 2004). Philosopher of imagination, Richard Kearney (1998), has researched the major theories of imagination in modern and postmodern European thought. His theory of ethics and narrative imagination provides a philosophical foundation for both imagination and narrative in education.

Imagination as I use the term is an activity that enables conceptual vitality-it can bring concepts to life. I regard it as a core - if tacit - component in the transitions from formal/rational to postformal/postrational thinking. ${ }^{17}$ Postformal educational researchers, Kincheloe and Steinberg (1993) claim "Post-formality is life-affirming as it transcends modernism's disdain and devaluation of the spiritual" (p. 309). I suggest that through imagination in our thinking we not only enliven concepts, but we bring the significance of life back into centre focus in our lifeworld, enhancing vitality and wellbeing.

Sloan's (1983) characterisation of insight-imagination best approaches my understanding of imagination. Sloan refers to it as a "higher order of consciousness," noting Bohm's distinction between "the deep act of imagination in insight from what he calls imaginative fancy" (p. 144). Sloan continues.

The cultivation of imagination does not mean the rejection of hard, lucid thought. It is, rather, the bringing of thought to life, permeating concepts and abstractions with life- 
giving images and inner energies through which thinking can penetrate and participate in the fullness of reality. (p. 192)

This aligns with Steiner's notion of imaginal thinking ${ }^{18}$ and Wilber's vision-logic. The cultivation of logic and rationality was significant in overcoming the deficiencies of earlier mythic consciousness, e.g. dogma and superstition (Gidley, 2007a). Yet the dominance of narrow instrumental forms of rationality, at the expense of other faculties, is arguably a psychic prison for children and young people and may jeopardise their conscious evolutionary development as adults. Formal education trains ${ }^{19}$ children to think in fixed concepts. I suggest that providing children primarily with dry, abstract, intellectual concepts may stunt their potential conceptual development and flexibility by fundamentalising concepts as dogmatic, unchanging facts. By contrast, postformal pedagogies that foreground conceptual imagination can be forces for conceptual vitality. Educating with conceptual vitality allows concepts to breathe and grow with children, so they evolve to meet children's developmental potential. This lays foundations for flexible, complex, process-oriented thinking, and a smooth transition to postformal-integral-planetary consciousness at the appropriate developmental moment.

Meanwhile, formal education seems caught within the inertness of formal thinking, as neo-fundamentalist educational reform agendas write more stale ideas about the already said (Lyotard, 2004). Several philosophers have emphasised the importance of imagination in education (Lyotard, 2004; Nuyen, 1998; Warnock, 1976; Whitehead, 1919). Deleuze challenges us "to bring something to life, to free life from where it is trapped, to trace lines of flight," (cited in St. Pierre, 2004, p. 287).

Could more facility with imagination assist in freeing education from where it is trapped?

\section{The Art of Pedagogical Life: Creating Imaginative "Lines of Flight"}

Education today is filled with broken paradoxes, and with their lifeless results. The great challenge of integrative education is to "think the world together," not apart, so that education can become the life-giving enterprise it was meant to be. (Palmer, 2007, Abstract)

There are two aspects to the art of cultivating pedagogical life. My primary interest is to promote the underappreciated notion of bringing concepts to life - to create living thinking — as a way of "thinking the world together." The second aspect, discussed subsequently, honours life through ecological, environmental and sustainability education (Jardine, 1998).

Using imagination to bring concepts to life has been central to Steiner pedagogy for eighty years, as a catalyst for the evolution of consciousness via both individual development and cultural regeneration (Gidley, 1998; Nielson, 2006; Sloan, 1992; Stehlik, 2008). Several contemporary educators emphasise imagination ${ }^{20}$ in school education (Egan, 1990; Eisner, 1985; Neville, 1989; Takaya, 2003, July). Others note its epistemological role in awakening higher knowledge and overcoming the dualisms fragmenting higher education (Gidley, 2003, 2006; Leonard \& Willis, 2008; McDermott, 2005). Imagination is also a focus of futures education (Gidley, 1998; Gidley, Bateman, \& Smith, 2004; Hicks, 1998; Milojevic, 2005).

In practical terms the healthy development of a teacher's imagination can be cultivated through such artistic activities as painting, creative writing, poetry and story telling to increase the likelihood of inspired teaching practice (Gidley, 2003; Leonard \& Willis, 2008). 
The cultivation of imagination is primarily nurtured in children through creative story telling and "pedagogy permeated with the arts and an aesthetic sensitivity" (Sloan, 1992, p. 47). A diversity of imaginative teaching processes is enacted in Steiner/Waldorf schools. A recent doctoral study focused on this aspect of Steiner pedagogy providing a worthwhile illumination of the cultivation of imagination in education, through: "drama, exploration, storytelling, routine, arts, discussion and empathy" (Nielson, 2006, p. 247). A unique pedagogical process that differentiates Steiner education is that writing is introduced first through pictures and pictograms prior to the abstract Roman alphabet. In my experience this supports evolution of consciousness in a meaningful way so that when children do learn to read the more abstract text they are able to read for meaning and thus are less likely to be functionally illiterate. ${ }^{21}$ For a pictorial overview of the evolution of literacy from Palaeolithic art, see Appendix C (Gidley, 2007b).

Imagination, however, is not of itself positive or negative. Its impact on the child depends on the content. The power of "the image" is well-known to the advertising industry, and futures researchers point to its transformative power (Boulding, 1988; Gidley, 1998; Polak, 1973). We live in a global cultural milieu, bombarded by pre-packaged images created by corporations to sell their products (Giroux, 2001; Steinberg \& Kincheloe, 2004) and where imagination is cultivated in an unhealthy way through media images of violence and fear. Several researchers critique the damaging effects of overexposure to negative media images (Clouder, Jenkinson, \& Large, 2000; Grossman, Degaetano, \& Grossman, 1999; Healy, 1998; Marshak, 1997; Pearce, 1992), calling for more critical awareness (Milojevic, 2005; Spina, 2004; Steinberg \& Kincheloe, 2004). Educators can help to balance the impact of negative mass media on children's wellbeing through providing critically reconstructed images of the good, beautiful and true, and by strengthening each child's own "image-making powers" (Sloan, 1992). The healthy effects of such positive imagination on young people's views and visions of the future and empowerment was found among Steiner educated Australian students (Gidley, 1998, 2002).

In addition to cultivating imagination, other kindred ways to affirm and enhance vitality and wellbeing through promoting pedagogical life include:

- Hand work - central to traditional and indigenous enculturation practices, and used pedagogically for a century (Dewey, 1972; Montessori, 1916/1964; Steiner, 1928/1972);

- Imaginative, postformal architecture (Jencks, 1997) and aesthetic interior design;

- Attention to rhythmical, cyclical, organic time vs. fast, mechanical time, to pace education more in line with our beings (McGill, 2005). See also Appendix B (Gidley, 2007b) for a postformal-integral-planetary analysis of modernist time-conceptions;

- Respect for nature through ecological imagination, and reverence for life (Jardine, 1998).

In summary, we should not underestimate the beneficial effects of enlivening education as a vital contribution to the resuscitation of an ailing planetary ecosystem.

\section{Pedagogical Wisdom}

Philosophical Perspectives: Creatively Integrating Multiplicities

Postformal thought ... is linked to creative production by virtue of its ... multiple views of reality and its multiple solutions, definitions, parameters, and methods during problem 
solving... [also combining] subjective and objective understanding... the same sorts of processes [can be observed] under the rubrics of wisdom. (Sinnott, 1998, p. 271)

The notion of wisdom - for millennia a central concept in the perennial philosophies (or wisdom traditions) - is a complex, elusive dimension. I propose that wisdom flourishes in contexts of reverence-care-love and life-filled conceptual imagination. Wisdom has attracted a resurgence of interest at the philosophical intersections between postformal psychology, education, and spirituality discourses. Perhaps this is not surprising, given the privileging of cognitive over emotional or vital ways of knowing in the Academy. Adult developmental psychologists suggest that wisdom embraces complexity, multi-perspectivality and creativity (Arlin, 1999; Labouvie-Vief, 1992; Sinnott, 1998; Sternberg, 1990, 2001).

Developmental psychologist Robert Sternberg (1998) has proposed a balance theory ${ }^{22}$ of wisdom arising from his triarchic theory of human intelligence-comprising analytical intelligence, creative intelligence and wisdom as practical intelligence. Psychologist Jan Sinnott (1998) views wisdom as a complex and integrative characteristic of postformal thought, explicitly linking it with spirituality and creativity. Arthur Koestler (1964/1989) foreshadowed the notion of creativity as a postformal feature. He claimed creativity is suppressed by the automatic routines of thought and behaviour that dominate our lives. Recent psychological research suggests that creativity and imagination are declining during childhood - in contrast to most aspects of cognitive development - perhaps lending support to Koestler's theory (Kaufman $\&$ Baer, 2006). This has raised the question as to whether it may be the "process of schooling itself, with its focus on the acquisition of knowledge and the production of correct (rather than imaginative) answers, which promotes this decline" (Kaufman \& Baer, 2006, p. 1). Kaufman and Baer (2005) characterise creativity as the ability to see things from novel perspectives reinforcing Sternberg's and Sinnott's links between wisdom, creativity, complexity, and ability to take multiple perspectives. Sternberg and Sinnott both focus on cultivating wisdom in education. Wisdom educator Caroline Bassett (2005b) proposes three major approaches: "wisdom as cognitive functioning, wisdom associated with various personal attributes, and wisdom understood as exceptional self-development" (Bassett, 2005b, para. 1). She contextualizes Sternberg's approach within the first, but omits Sinnott's research. Bassett situates her own work in the third approach, which she associates with postformal thinking, transformative learning and aesthetics/creativity.

In this complex territory of integrating multiple perspectives, Wilber's integral framework could contribute theoretical coherence to cultivating wisdom in education. But there is a complex aesthetics to how this actually works in the art of pedagogical practice (Rose \& Kincheloe, 2003; Steiner, 1928/1972). Rose and Kincheloe point to the importance of "complex aesthetics" in developing and integrating the multiple perspectives of postformal thinking:

As teachers think about the relationship between the aesthetic and the intellectual, they develop pedagogical strategies that encourage engagement... This involves the recognition of multiple ways of knowing which assists more students to discover that they are imaginative, creative and smart. (p. 46)

Kaufman and Sternberg's (2006) international research on creativity found aesthetic orientation to be a personality trait associated with creativity. This also suggests a role for aesthetic education in cultivating wisdom. Sternberg (2005) pointed to research on wisdom as a 
balance of cognitive, conative/behavioural and affective ${ }^{23}$ human abilities. This has been extended to four wisdom dimensions: discerning (cognitive), respecting (affective), engaging (active) and transforming (reflective) (Bassett, 2005a, p. 7). Through affect, aesthetic education can contribute to wisdom. There is extensive literature on the moral, cultural and integrative value of aesthetic education beginning with Plato (Gidley, 2002). Steiner pedagogy carries the romantic-aesthetic philosophical legacy of Schelling, Goethe and Schiller (1954/1977). Art educators also emphasise the importance of aesthetics in balancing cognicentrism in education (Abbs, 2003; Eisner, 1985; Read, 1943). Through art, drama and movement, students can see the complex paradoxes of "both/and" relationships, not just the binaries of "either/or."

Finally, wisdom is about waking up - to our own presence and the presence of others. The complex wisdom embedded in the art of education demands being awake in every moment. ${ }^{24} \mathrm{As}$ Tobin Hart (2001b) states: "Education for wisdom is not about simply being taught but about waking up. Waking up requires a certain kind of energy, certain capacities for taking the world into our consciousness" (p. 10). Steiner (1967), in 1922 lectures, already indicated this.

First of all, the teachers must be awakened, and then the teachers must awaken the children and young people... what matters is a question of awakening, for evolution has made human beings fall into a sleep that is filled with intellectualistic dreams. (p. 23-28)

The Art of Pedagogical Wisdom: The Many Faces of the Muse $e^{25}$

Good teachers... are able to weave a complex web of connections among themselves, their subjects, and their students so that students can learn to weave the world for themselves. (Palmer, 1998, p. 11)

To counter the prescriptive and somnolent trends, we need more than a model or framework; we need to hear the creative voices of educators who have cultivated pedagogical wisdom as an art. Maggie MacLure's (2006b) art is her critical passion. She claims "Interruptive methods are needed to try to crack... the inertia coded in the pedagogic encounter" (p. 731). She proposes a baroque educational philosophy as a creative way to interrupt and resist closure (Deleuze \& Conley, 1992). MacLure (2006c) characterises baroque education ${ }^{26}$ with such terms as "entangled, disruptive... artistic, aesthetic and literary." She notes that by utilising "dislocation of time and space... [and] periodic interruptions of the "other" "baroque educational philosophy offers "resistance to audit culture... [and] disrupts closure seeking." I was intrigued to recognise that many of these baroque features resemble Steiner education - sometimes regarded as quaintly anachronistic. Yet from MacLure's (2006c) perspective this "defamiliarisation" with the "mythic immediacy of the educational present" is of immense value in moving beyond the "closure-seeking tendencies" of the audit culture. So how might such "left-field" aesthetic approaches as Steiner education or Deleuze's baroque philosophy lead to wisdom, postformal thinking, or even qualify as "good education"?

What may be most effective in cultivating wisdom in education is utilising complex thinking and creativity to represent knowledge from multiple perspectives while showing their integral interconnectedness through our creative artfulness. This can be assisted by approaches that acknowledge multiple intelligences (Gardner, 1996), or lines of ability (Wilber, 2004).

In my own pedagogical practice I continually danced between disciplinary emphasis and transdisciplinary contextualisation: conceptually, through imaginative vitality; visually, through 
a picture or diagram; imaginatively, through the narration of a story, poem, song, dance, or roleplay; and/or experientially, through handwork, gardening, or off-campus excursions. Other ways to enhance wisdom are to ensure children learn critically under-appreciated human values. Cultural pluralism and multilingualism need more educational space in a multicultural global world (de Souza, 2006; Inayatullah, 2002; Milojevic, 2005). Cosmopolitanism as a significant feature of planetary consciousness is discussed in Appendix B (Gidley, 2007b).

Awareness of the value of play in education goes back two centuries to Schiller (1954/1977) and Jean Paul Richter (Pridmore, 2004). Educator Eugene Schwartz (1999) sees play as a foundation for conceptual knowledge. Kincheloe and Steinberg (1993) link it to postformalilty. Play can be philosophically grounded by the jouissance of poststructuralist word play (Derrida, 2001; Kristeva, 1982) and integral developmental theory (Gordon \& EsbjörnHargens, 2007). While substantial literature suggests that violent video games have a destructive influence on children (Benoit, 2000; Clouder, Jenkinson, \& Large, 2000; Grossman, Degaetano, \& Grossman, 1999; Healy, 1998; Pearce, 1992) one study contests this (Spina, 2004). As an alternative, non-violent strategy board games could playfully contribute to the development of postformal, complex systems thinking in adolescence.

Perhaps even more subjugated in most education settings are well-being and happiness (Abbs, 2003; Eckersley, Wierenga, \& Wyn, 2006; Noddings, 2003); laughter, humour and even frivolity (Johnson, 2005; Koestler, 1964/1989; MacLure, 2006a). It is encouraging to see these broader human literacies opening up through the creativity of postformal educational offerings.

\section{Pedagogical Voice}

\section{Philosophical Perspectives: Languaging the World of Words and Sound}

The poetics of education ... calls for the endless acts of cultural reincarnation - acts which enable students to see with new eyes and to speak with new tongues. (Abbs, 2003, p. 17)

I am using the term pedagogical voice as a broad palette to include family resemblances ${ }^{27}$ among postformal developments in language and linguistics, speech education, the range of voices of teachers and children, and education in awareness of sound and silence.

Both Steiner and Gebser emphasised the significance of language awareness, poetic expression and creativity as part of the emerging consciousness. The re-integration of philosophy and poetry in western European culture was begun in the late $18^{\text {th }}$ century by English and German romantic philosopher-poets such as William Blake, Schelling, Novalis and the Schlegel brothers (Richards, 2002; Royce, 1892/2001; Steiner, 1914/1973). Contemporary philosophical awareness of how we language the world emerged with the linguistic turn (Rorty, 1967). The linguistic turn was influenced by Ferdinand De Saussure's linguistic structuralism (Matthews, 1996), the language-games of Ludwig Wittgenstein's (1968) later anti-dogmatic philosophy, and the notion of metanarratives by Lyotard (2004). Linguistic consciousness was deepened by French poststructuralists (Deleuze, 1968/1994; Derrida, 2001; Foucault, 1986; Kristeva, 1982).

Developmental psychologist Susanne Cook-Greuter (2000) refers to the "constructaware" stage in which awareness of what she calls "the language habit" arises (p. 235). I use the term language reflexivity for this concept. Recent research on the relationship between integral theory and postmodernism explored relationships between Wilber's vision-logic, Cook-Greuter's 
construct-aware stage and Derrida's deconstruction (Hampson, 2007). Other $20^{\text {th }}$ century thinkers have drawn attention to the developmental significance of reflexivity and creativity in languaging (Abbs, 2003; Barfield, 1985; Gangadean, 1998; Subbiondo, 2003; Thompson, 1998). Evidence of the emergence of new forms of creative languaging is found in the use of neologisms ${ }^{28}$ (Derrida, 2001; Gangadean, 1998; St. Pierre, 2004).

Steiner $(1926 / 1986,1984)$ wrote extensively about the conscious development of language and speech, and its significance for human evolution. His emphasis on oral as well as written language has remained a core component of Steiner/Waldorf education. He also developed a complex, enlivening movement art called eurythmy ${ }^{29}$ based on his understanding of how consciousness co-evolves with speech and language (Steiner, 1931/1984). Eurythmy is a largely undiscovered postformal art-form with the potential to enhance higher order consciousness through complex creativity and body-mind integrality. It is enacted artistically with speech or music, or therapeutically. Research into the potential of eurythmy in systems theory has begun (Deijmann). It could be philosophically located within the emergent aesthetic literacies arising from the critique of narrow literacies (Gale, 2005).

In the context of high stakes testing and performance outcomes pedagogical voice and language reflexivity are not high on educational agendas. Yet research suggests that sustained exposure to electronic "voices"- television, computers and electronic games - may impair early speech development (Clouder, Jenkinson, \& Large, 2000; Healy, 1998; Pearce, 1992). While not advocating the elimination of the latter, more creative attention to the nuances of the living word could facilitate postformal language sensibility at appropriate developmental moments.

\section{The Art of Pedagogical Voice: Silent Spaces and Sensitive Sounds}

On better days we struggle to tear off the tacky film which covers our educational and poetic aspirations, resist the counterfeit version of consciousness and struggle to locate the smothered springs of renewal. (Abbs, 2003, p. 1)

What kinds of environments are we providing for our children? In our noise-polluted urban worlds it is a huge challenge to draw conscious attention to sound, let alone begin to refine and educate the delicate senses in relation to it. By contrast, an educational environment where spoken human language is valued over written and electronic voices for young children may provide an antidote. Poems, singing, drama and natural conversation are all vocal methods that can greatly benefit the development of written language. Additional oral methods include: chanting, oration, re-telling stories, tongue twisters and word play. Learning a second or third language is invaluable for enhancing sound awareness, and ability to see things from multiple perspectives, not to mention expanding awareness of the cultural other.

Consciousness of how we voice ourselves with children also makes space for silence, which can be a very powerful arena for "holding the space." David Jardine points to the importance of cultivating silent spaces in our classrooms.

We must begin to believe again that silence may be our most articulate response. Silence must become possible again. In the midst of silence, a word, a gesture, a cry, can finally mean something, because we can finally hear, finally listen. (Jardine, 1998, pp. 30-31) 
Kincheloe and Steinberg (1993) refer to the respect the Ancient Greeks had for "the lulls of profound silence that periodically spread across a room filled with conversation" perceiving them as representing the presence of Hermes. "By silencing the everyday babble, Hermes allowed the Greeks to tap their imagination, fears, hopes and passions" (p. 304).

In a pedagogical environment where teachers are reflexively conscious of their own language and voice, and respectful of children's voices, the space can be opened for children to voice their hopes and fears, interests and dreams. ${ }^{30}$ Recent educational research involves the participation of children's voices in education ${ }^{31}$ and research (Graham \& Fitzgerald, 2007). Research on non-violent communication may also be relevant in this regard.

The world of sound and tone-which incidentally is carried on the air-is heavily polluted today, just like the particle pollution in the air. How often do urban children hear birds or insects sing, wind whistle, creeks babble or waves break? Attention to sound education has been severely neglected, other than through the obvious formal process of music education. We can begin with very young children by allowing them to 'hear a pin drop', or taking them to environments where they can actively listen to natural sounds. Arguably, a joyful teacher starting a class with a song is far less likely to attract resistance than one who shouts to be heard.

In these times, when so much education has become reduced to vocational training, it might be useful to consider that the word vocation - from voce-originally meant spiritual calling. How are we facilitating the deep listening that might enable children to hear such a calling (Hillman, 1996). While not recommending meditation for children, listening practices, observation of nature, and the inner stillness of absorption in a creative activity - e.g., painting, wood carving, weaving - are foundations for stillness, open mindedness and open-heartedness.

In summary, an authentic pedagogical voice may balance the inauthenticity of 'voice'mail, 'chat'-rooms, and 'talking' computers. Educators carry a developmental-even evolutionary - responsibility through our choice of words, our tone of voice, the timing of our silences, our authentic presence, and how well we enable children to express theirs.

\section{The Pedagogical Languages ${ }^{32}$ of Love, Life and Wisdom}

From multiple points of view the times we are living in are highly significant. As a species we have achieved a peak in terms of scientific and technological development, yet the damage we have done to the earth in the process has brought the whole notion of progress into question. Alternatively, the word progress could mean a growth and maturing of consciousness and moral/ethical/spiritual values through the nurturing of love, life and wisdom, rather than information acquisition and consumerism which are primarily geared to material progress.

The notion that consciousness is evolving has emerged in spiritual and religious studies, developmental psychology, cultural history and integral theory. New thinking is evident in the new sciences, poststructural philosophy, and integral, holistic, planetary perspectives. The potential impact for formal education is twofold, raising the following key questions. If new postformal ways of thinking are emerging that are complex, dialectical, creative and selfreflective, how is education responding to this? Secondly, if the fragility of our current planetary ecological environment can be assisted by fostering wiser, more caring, more life-enhancing, integral, planetary consciousness, how can educators achieve this? This paper has brought these challenging issues into the education discourse by planting seeds for postformal-integralplanetary pedagogies. Arising from the intersection of the evolution of consciousness discourse and postformal educational approaches, my educational philosophy distils four core pedagogical 
values - love, life, wisdom and language/voice. I suggest these are central to education for spirituality, care and wellbeing.

\section{Acknowledgements}

I acknowledge my friend and colleague, Gary Hampson for editorial support and for our caring, vital and creative dialogues.

\section{References}

Abbs, P. (2003). Against the flow: The arts, postmodern culture and education. London: RoutledgeFalmer.

Altobello, R. (2007). Concentration and contemplation: A lesson in learning to learn. Journal of Transformative Education, 5(4), 354-371.

Arlin, P. K. (1999). The wise teacher: A developmental model of teaching. Theory into Practice, $38(1), 12-17$.

Barfield, O. (1985). History in English words. Herndon, VA: Lindisfarne Books.

Bassett, C. (2005a). Emergent wisdom: Living a life in widening circles. ReVision: A Journal of Consciousness and Transformation, 27(4), 6-11.

Bassett, C. (2005b, October). Wisdom in three acts: Using transformative learning to teach for wisdom [Eletronic version]. Paper presented at the Sixth International Transformative Learning Conference, East Lansing, Michigan.

Benedikter, R. (2005). Postmodern spirituality: A dialogue in five parts. Retrieved 28 June, 2006, from http://www.integralworld.net/index.html?benedikter1.html

Benoit, M. (2000). The dot.com kids and the demise of frustration tolerance. In C. Clouder, S. Jenkinson \& M. Large (Eds.), The future of childhood. Gloucestershire: Hawthorn Press.

Bergson, H. (1911/1944). Creative evolution (A. Mitchell, Trans.). New York: Macmillan \& Co. Bohm, D. (1980). Wholeness and the implicate order. London: Ark paperbacks.

Boulding, E. (1988). Image and action in peace building. Journal of Social Issues, 44(2), 17-37.

Bouma, G. (2006). Australian soul: Religion and spirituality in the 21st century. Cambridge: Cambridge University Press.

Brady, R. (2007). Learning to stop, stopping to learn: Discovering the contemplative dimension in education. Journal of Transformative Education, 5(4), 372-394.

Braud, W. (1998). Integral inquiry: Complementary ways of knowing, being and expressing. In W. Braud \& R. Anderson (Eds.), Transpersonal research methods for the social sciences: Honoring human experience. Thousand Oaks: Sage Publications.

Cartwright, K. B. (2001). Cognitive developmental theory and spiritual development. Journal of Adult Development 8(4), 213-220.

Chater, M. (2006). Just another brick in the wall: Education as violence to the spirit. International Journal of Children's Spirituality, 11(1), 47-56.

Clouder, C., Jenkinson, S., \& Large, M. (2000). The future of childhood. Gloucestershire: Hawthorn Press.

Combs, A. (2002). The radiance of being: Understanding the grand integral vision: Living the integral life. St. Paul: Paragon House.

Commons, M. L., \& Richards, F., A. (2002). Organizing components into combination: How stage transition works. Journal of Adult Development, 9(3), 159-177. 
Commons, M. L., Trudeau, E. J., Stein, S. A., Richards, F., A, \& Krause, S. R. (1998). The existence of developmental stages as shown by the hierarchical complexity of tasks. Developmental Review, 8(3), 237-278.

Cook-Greuter, S. R. (2000). Mature ego development: A gateway to ego transcendence. . Journal of Adult Development, 7(4), 227-240.

Coryn, C. L. S., Schröter, D. C., \& Scriven, M. (2005). A call to action: The first international congress of qualitative inquiry. Journal of MultiDisciplinary Evaluation 3(October), 155165.

Coulter, D. J. (1991). Montessori and Steiner: A pattern of reverse symmetries. Holistic Education Review, 4(2 (Summer)), 30-32.

Dator, J. (2000). The futures for higher education: From bricks to bytes to fare thee well! In S. Inayatullah \& J. Gidley (Eds.), The university in transformation: Global perspectives on the futures of the university. Westport, CT: Bergin \& Garvey.

de Souza, M. (2006). Educating for hope, compassion and meaning in a divisive and intolerant world. International Journal of Children's Spirituality, 11(1), 165-175.

Deijmann, W. (n. d.). More on systems thinking, personal mastery and eurythmy [Electronic Version] Retrieved February 19, 2007, from http://web.archive.org/web/20030623094819/http://www.dialoog.net/deijmann/eurythmy 2.htm\#Dyn.

Deleuze, G. (1968/1994). Difference and repetition (First published in French 1968). New York: Columbia University Press.

Deleuze, G., \& Conley, T. (1992). The fold: Leibniz and the baroque. Minneapolis: University of Minnesota Press.

Denzin, N. (2005). The first international congress of qualitative inquiry. Qualitative Social Work, 4(1), 1105-1111.

Derrida, J. (2001). Structure, sign, and play in the discourse of the human sciences [Electronic Version]. Writing and Difference, 278-294. Retrieved December 9, 2006, from http://www.hydra.umn.edu/derrida/sign-play.html.

Dewey, J. (1972). The early works, 1882-1898, Volume 5. Illinois: Carbondale and Edwardsville, Southern Illinois University Press.

Earley, J. (1997). Transforming human culture: Social evolution and the planetary crisis. New York: SUNY Press.

Eckersley, R., Cahill, H., Wierenga, A., \& Wyn, J. (Eds.). (2007). Generations in dialogue about the future: The hopes and fears of young Australians. Melbourne, VIC: Australian Youth Research Centre and Australia 21.

Eckersley, R., Wierenga, A., \& Wyn, J. (2006). Flashpoints and signposts: Pathways to success and wellbeing for Australia's young people: Australian Youth Research Centre, University of Melbourne.

Egan, K. (1990). Romantic understanding: The development of rationality and imagination, ages 8-15. London: Routledge.

Egan, K. (1997). The educated mind: How cognitive tools shape our understanding. Chicago: The University of Chicago Press.

Eisler, R. (2001). Partnership education in the 21st century. Journal of Futures Studies, 5(3), 143-156.

Eisner, E. (1985). The educational imagination: On the design and evaluation of school programs (2nd ed.). New York: Macmillan. 
Eisner, E. (2000). Those who ignore the past...: 12 Easy lessons for the next millennium Journal of Curriculum Studies, 32(2), 343-357.

Erricker, J., Ota, C., \& Erricker, C. (Eds.). (2001). Cultural, religious and social differences: New perspectives for the 21st century. Brighton: Sussex Academic Press.

Falcone, G. J. (2000). The relationship of postformal thought to conceptions of wisdom as mediated by age and education. Unpublished Ed.D., Rutgers The State University of New Jersey - New Brunswick and University of Medicine and Dentistry of New Jersey, New Jersey.

Ferrer, J., Romero, M., \& Albareda, R. (2005). Integral transformative education: A participatory proposal. Journal of Transformative Education, 3(4), 306-330.

Finser, T., M. . (2001). School renewal: A spiritual journey for change. Great Barrington, MA: Anthroposophic Press.

Foucault, M. (1986). Text/context of other space. Diacritics, 16(1), 22-27.

Foucault, M. (2005). The hermeneutics of the subject: Lectures at the Collège de France 19811982. New York: Palgrave MacMillan.

Fraser, M., Kember, S., \& Lury, C. (2005). Inventive life: Approaches to the new vitalism. Theory, Culture \& Society, 22(1), 1-14.

Gale, R. (2005). Aesthetic literacies and the "Living of lyrical moments." Journal of Cognitive Affective Learning, 2(1), 1-9.

Gangadean, A. (1998). Between worlds: The emergence of global reason. New York: Peter Lang.

Gangadean, A. (2006). A planetary crisis of consciousness: From ego-based cultures to a sustainable global world Kosmos: An Integral Approach to Global Awakening V, 37-39.

Gardner, H. (1996). Probing more deeply into the theory of multiple intelligences. NASSP Bulletin, 80(583), 1-7.

Gare, A. (1999). Speculative metaphysics and the future of philosophy: The contemporary relevance of Whitehead's defence of speculative metaphysics. Australasian Journal of Philosophy, 77(2), 127-145.

Gebser, J. (1949/1985). The ever-present origin. Athens, Ohio: Ohio University Press.

Gebser, J. (1996). The conscious and the unconscious: A Misleading Choice. Integrative Explorations Journal, 3, 84-85.

Gidley, J. (1998). Prospective youth visions through imaginative education. Futures, 30(5), 395408.

Gidley, J. (2001). 'Education for all' or education for wisdom? In M. Jain (Ed.), Unfolding Learning Societies: Deepening the Dialogues. Udaipur: Shikshantar.

Gidley, J. (2002). Holistic education and visions of rehumanized futures. In J. Gidley \& S. Inayatullah (Eds.), Youth futures: Comparative research and transformative visions (pp. 155-168). Westport, Connecticut: Praeger.

Gidley, J. (2003, September). Empowering teachers to work with imagination. Paper presented at the 3rd International Soul in Education Conference, Byron Bay, Australia.

Gidley, J. (2005). Giving hope back to our young people: Creating a new spiritual mythology for Western culture. Journal of Futures Studies, 9(3), 17-30.

Gidley, J. (2006). Spiritual epistemologies and integral cosmologies: Transforming thinking and culture. In S. Awbrey, D. Dana, V. Miller, P. Robinson, M. M. Ryan \& D. K. Scott 
(Eds.), Integrative learning and action: A call to wholeness. New York: Peter Lang Publishing.

Gidley, J. (2007a). Educational imperatives of the evolution of consciousness: The integral visions of Rudolf Steiner and Ken Wilber. International Journal of Children's Spirituality, 12(2), 117-135.

Gidley, J. (2007b). The evolution of consciousness as a planetary imperative: An integration of integral views. Integral Review: A Transdisciplinary and Transcultural Journal for New Thought, Research and Praxis, 5, 4-226.

Gidley, J. (2008). Evolving Education: A postformal-integral-planetary gaze at the evolution of consciousness and the educational imperatives (Unpublished PhD dissertation), Southern Cross University.

Gidley, J., Bateman, D., \& Smith, C. (2004). Futures in education: Principles, practice and potential. Melbourne: Australian Foresight Institute.

Giroux, H. A. (1999/2005). Schooling and the struggle for public life: Democracy's promise and education's challenge Boulder, CO: Paradigm Publishers.

Giroux, H. A. (2001). Stealing innocence: Corporate culture's war on children New York: Palgrave Macmillan.

Glazer, S. (Ed.). (1994). The heart of learning: Spirituality in education. New York: Jeremy P. Tarcher / Putnam.

Goerner, S. (2000). Rethinking education in the light of great change. New Horizons for Learning(July).

Goodenough, U., \& Deacon, T. W. (2006). The sacred emergence of nature. In P. Clayton (Ed.), Oxford handbook of science and religion (pp. 853-871). Oxford: Oxford University Press.

Gordon, G., \& Esbjörn-Hargens, S. (2007). Are we having fun yet? An exploration of the transformative power of play. Journal of Humanistic Psychology, 47(2), 198-222.

Graham, A., \& Fitzgerald, R. (2007, November 25-29). Progressing the 'impact' agenda in education: Including children \& young people in research Paper presented at the 2007 Australian Association for Research in Education conference, 'Proving or Improving', Fremantle WA.

Grigg, L., Johnston, R., \& Milson, N. (2003). Emerging issues for cross-disciplinary research: Conceptual and empirical dimensions. Canberra: DEST, Commonwealth of Australia.

Grossman, D., Degaetano, G., \& Grossman, D. (1999). Stop teaching our kids to kill: A call to action against TV, movie and video violence. NY: Random House.

Hampson, G. (2007). Integral reviews postmodernism: The way out is through Integral Review: A Transdisciplinary and Transcultural Journal for New Thought, Research and Praxis 4, 108-173.

Hart, T. (1998). A dialectic of knowing: Integrating the intuitive and the analytic. Encounter: Education for Meaning and Social Justice, 11, 5-16.

Hart, T. (2000). Deep empathy. In T. Hart, P. Nelson \& K. Puhakka (Eds.), Transpersonal knowing: Exploring the horizon of consciousness (pp. 253-270). Albany: State University of New York Press.

Hart, T. (2001a). From information to transformation: Education for the evolution of consciousness. New York: Peter Lang.

Hart, T. (2001b). Teaching for wisdom. Encounter: Education for Meaning and Social Justice, 14(2), 3-16. 
Hatt, B. E. (2005). Pedagogical love in the transactional curriculum. Journal of Curriculum Studies, 37(6), 671-688.

Healy, J. M. (1998). Failure to connect: How computers affect our children's minds - and what we can do about it. New York: Touchstone.

Hefner, P. (1998). The spiritual task of religion in culture: An evolutionary perspective. Zygon: Journal of Religion and Science, 33(4), 535-544.

Hicks, D. (1998). Identifying sources of hope in post-modern times. In D. Hicks \& R. Slaughter (Eds.), World yearbook of education 1998: Futures education. London: Kogan Page.

Hillman, J. (1996). The soul's code: In search of character and calling. New York: Random House.

Holdrege, C. (2005). Editorial to Goethe's delicate empiricism Janus Head, 8(1), 12-13.

Huston, T. (2007). A brief history of evolutionary spirituality. What is Enlightenment: Redefining Spirituality for an Evolving World, 76-84.

Inayatullah, S. (2002). Youth dissent: Multiple perspectives on youth futures. In J. Gidley \& S. Inayatullah (Eds.), Youth futures: Comparative research and transformative visions (pp. 19-30). Westport, Connecticut: Praeger.

Jain, M., \& Jain, S. (Eds.). (2003). McEducation for all? Udaipur: Shikshantar.

Jain, M., Miller, V., \& Jain, S. (Eds.). (2001). Unfolding learning societies: Deepening the dialogues (Vol. April 2001). Udaipur, Rajasthan, India: The People's Institute for Rethinking education and Development.

Jantsch, E. (1980). The self-organising universe: Scientific and human implications of the emerging paradigm of evolution New York: Pergamon Press.

Jardine, D. W. (1998). To dwell with a boundless heart: Essays in curriculum theory, hermeneutics, and the ecological imagination. New York: Peter Lang Publishing.

Jencks, C. (1997). The architecture of the jumping universe: A polemic: How complexity science is changing architecture and culture West Sussex: John Wiley \& Sons.

Johnson, H. (2005). Counteracting performativity in schools: The case for laughter as a qualitative redemptive indicator International Journal of Children's Spirituality, 10(1), 81-96.

Kaufman, J., C, \& Baer, J. (2006). Creativity and reason in cognitive development. New York: Cambridge University Press.

Kaufman, J., C, \& Baer, J. (2005). Creativity across domains: Faces of the muse. Mahwah, N.J.: Lawrence Erlbaum Associates.

Kaufman, J., C, \& Sternberg, R., J. (Eds.). (2006). The international handbook of creativity. New York: Cambridge University Press.

Kearney, R. (1998). Poetics of imagining: Modern to post-modern. Edinburgh: University Press.

Kegan, R. (1994). In over our heads: The mental demands of modern life. Cambridge, Massachusetts: Harvard University Press.

Kessler, R. (2000a). The soul of education: Helping students find connection, compassion and character at school. Alexandria, VA: Association for Supervision and Curriculum Development.

Kessler, R. (2000b). The teaching presence. Virginia Journal of Education, 944(2), 7-10.

Kincheloe, J., \& Berry, K. (2004). Rigour and complexity in educational research: Conceptualising the bricolage. Berkshire: Open University Press. 
Kincheloe, J., \& Steinberg, S. (1993). A tentative description of post-formal thinking: The critical confrontation with cognitive theory. Harvard Educational Review, 63(3), 296320.

Koestler, A. (1964/1989). The act of creation. London: Arkana.

Kohlberg, L. (1990). Which postformal stages are stages? In M. Commons, C. Armon, L. Kohlberg, F. Richards, A, T. A. Grotzer \& J. D. Sinnott (Eds.), Adult development, Volume 2: Models and methods in the study of adolescent and adult thought. Westport, CT: Praeger.

Kramer, D., A. (1983). Post-formal operations? A need for further conceptualization. Human Development, 26, 91-105.

Kristeva, J. (1982). Desire in language: A semiotic approach to literature and art. New York, NY: Columbia University Press.

Labouvie-Vief, G. (1992). Wisdom as integrated thought: Historical and developmental perspectives. In R. Sternberg, J. \& C. A. Berg (Eds.), Wisdom: Its nature, origins, and development. Cambridge: Cambridge University Press.

László, E. (2006). The chaos point: The world at the crossroads. Charlottsville, VA: Hampton Roads Publishing Company, Inc.

László, E. (2007). Science and the akashic field: An integral theory of everything. Rochester, Vermont: Inner Traditions.

Leonard, T., \& Willis, P. (Eds.). (2008). Pedagogies of the imagination: Mythopoetic curriculum in educational practice. Berlin: Springer.

Lyotard, J.-F. (2004). The postmodern condition: A report on knowledge. Manchester: Manchester University Press.

MacLure, M. (2006a). Entertaining doubts: On frivolity as resistance. In J. Satterthwaite, W. M. Martin \& L. Robert (Eds.), Discourse, resistance and identity formation. London Trentham.

MacLure, M. (2006b). The bone in the throat: Some uncertain thoughts on baroque method. International Journal of Qualitative Studies in Education, 19 (6 November-December), 729-745.

MacLure, M. (2006c, 27th November). 'The bone in the throat': some uncertain thoughts on baroque method. Paper presented at the Engaging Pedagogies, AARE 2006 International Education Research Conference, Adelaide.

Marshak, D. (1997). The common vision: Parenting and educating for wholeness. New York: Peter Lang.

Matthews, E. (1996). Twentieth century French philosophy. Oxford: Oxford University Press.

McDermott, R. (2005). An Emersonian approach to higher education. ReVision: A Journal of Consciousness and Transformation, 28(2), 6-17.

McGill, J. (2005). Reflecting on the pace of schooling. 2006, retrieved December 7, from http://www.torontowaldorfschool.com/pdf/refpace.pdf

Miller, J., P. (2000). Education and the soul: Towards a spiritual curriculum. Albany, NY: State University of New York Press.

Miller, R. (1990). What are schools For? Holistic education in American culture. Brandon, Vermont: Holistic Education Press.

Miller, R. (2000). Education and the evolution of the cosmos. In R. Miller (Ed.), Caring for new life: Essays on holistic education. Brandon, VT: Foundation for Educational Renewal. 
Miller, R. (2006). Making connections to the world: Some thoughts on holistic curriculum. Encounter: Education for Meaning and Social Justice, 19(3).

Miller, R. (Ed.). (1993). The renewal of meaning in education: Responses to the cultural and ecological crisis of our times (CD-ROM ed.). Brandon, VT: Great Ideas in Education.

Milojevic, I. (2005). Educational futures: Dominant and contesting visions London: Routledge.

Montessori, M. (1916/1964). The Montessori method. New York: Schoken Books.

Montuori, A. (1999). Planetary culture and the crisis of the future. World Futures: the Journal of General Evolution, 54(4), 232-254.

Montuori, A. (2006). The quest for a new education: from oppositional identities to creative inquiry. ReVision, 28(3), 4-17.

Morin, E. (2001). Seven complex lessons in education for the future. Paris: UNESCO.

Morin, E., \& Kern, A. B. (1999). Homeland earth: A manifesto for the new millennium (S. Kelly, R. Lapoint, Trans.). Cresskill, NJ: Hampton Press.

Nava, R. G. (2001). Holistic education: Pedagogy of universal love (M. N. Rios \& G. S. Miller, Trans.). Brandon, VT: Holistic Education Press.

Neville, B. (1989). Educating psyche: Emotion, imagination, and the unconscious in learning. Melbourne: Collins Dove.

Nicolescu, B. (2002). Manifesto of transdisciplinarity (K. Voss, Trans.). New York: SUNY Press.

Nielson, T. W. (2006). Towards a pedagogy of imagination: A phenomenological case study of holistic education. Ethnography and Education, 1(2), 247-264.

Noddings, N. (2003). Happiness and education. Cambridge: Cambridge University Press.

Noddings, N. (2005). Caring in education [Electronic Version]. The encyclopedia of informal education. Retrieved January 7, from www.infed.org/biblio/noddings caring in education.htm.

Nuyen, A. T. (1998). Jean-Francois Lyotard: Education for imaginative knowledge. In M. Peters (Ed.), Naming the multiple: Poststructuralism and education. Westport, CT: Bergin \& Garvey.

Orr, D. (1994). Earth in mind: On education, environment, and the human prospect. Washington D.C: Island Press.

Palmer, P. (1998). The courage to teach. San Francisco: Jossey-Bass.

Palmer, P. (2007). The precision of poetry \& the passion of science: An education in paradox uncovering the heart of higher education. Paper presented at the Integrative Learning for Compassionate Action in an Interconnected World, San Francisco.

Pearce, J. C. (1992). Evolution's end: Claiming the potential of our intelligence. San Francisco, CA: Harper.

Polak, F. (1973). The image of the future (E. Boulding, Trans.). San Francisco: Jossey-Bass.

Pribram, K. (2006). Holism vs. wholism. World Futures: the Journal of General Evolution, 62, 42-46.

Pridmore, J. (2004). 'Dancing cannot start too soon': Spiritual education in the thought of Jean Paul Friedrich Richter. International Journal of Children's Spirituality, 9(3), 279-291.

Ray, P. (1996). The rise of integral culture. Noetic Sciences Review, 37(Spring), 4.

Read, H. (1943). Education through art. London: Faber and Faber.

Richards, R. J. (2002). The romantic conception of life: Science and philosophy in the age of Goethe. Chicago: University of Chicago Press. 
Riegel, K., F. (1973). Dialectical operations: The final period of cognitive development. Human Development, 16, 346-370.

Robbins, B. D. (2006). The delicate empiricism of Goethe: Phenomenology as a rigourous science of nature [Electronic Version]. Indo-Pacific Journal of Phenomenology, 6, 13. Retrieved 10 Novemember 2007.

Rorty, R. (1967). The linguistic turn: Essays in philosophical method. Chicago: University of Chicago Press.

Rose, K., \& Kincheloe, J. (2003). Art, culture and education: Artful teaching in a fractured landscape. New York: Peter Lang.

Royce, J. (1892/2001). Josiah Royce's "The spirit of modern philosophy", Lecture 6: The romantic school in philosophy. The Mead Project Retrieved February 7, 2004

Russell, P. (2002). From science to God: A physicist's journey into the mystery of consciousness. Novato, CA: New world Library.

Schiller, F. (1954/1977). On the aesthetic education of man - in a series of letters (First published in 1795). New York: Frederick Ungar Publishing.

Schwartz, E. (1999). Millennial child: Transforming education in the twenty-first century. Anthroposophic Press: New York.

Scott, D. (2000). Spirituality in an integrative age. In V. Kazanjian, H. Jr. \& P. Laurence (Eds.), Education as transformation: Religious pluralism, spirituality, and a new vision for higher education. New York: Peter Lang Publishing.

Sinnott, J. D. (1994). Development and yearning: Cognitive aspects of spiritual development. Journal of Adult Development, 1(2), 91-99.

Sinnott, J. D. (1998). The development of logic in adulthood: Postformal thought and its applications. New York: Springer.

Sinnott, J. D. (2005). The dance of the transforming self: Both feelings of connection and complex thought are needed for learning. New Directions for Adult and Continuing Education, 108(Winter), 27-37.

Sloan, D. (1983). Insight-imagination: The emancipation of thought and the modern world. Westport, CT: Greenwood.

Sloan, D. (1992). Imagination, education and our postmodern possibilities. ReVision: A Journal of Consciousness and Transformation, 15(2), 42-53.

Spina, S. U. (2004). Power plays: Video games' bad rap. In S. Steinberg \& J. Kincheloe (Eds.), Kinderculture: The corporate construction of childhood. Boulder, Colorado: Westview Press.

St. Pierre, E. A. (2004). Deleuzian concepts for education: The subject undone. Educational Philosophy and Theory 36(3), 283-296.

Stehlik, T. (2008). Thinking, feeling and willing: How Waldorf schools provide a creative pedagogy which nurtures and develops imagination. In T. Leonard \& P. Willis (Eds.), Pedagogies of the imagination: Mythopoetic curriculum in educational practice. Berlin: Springer.

Steinberg, S., \& Kincheloe, J. (Eds.). (2004). Kinderculture: The corporate construction of childhood. Boulder, Colorado: Westview Press.

Steiner, R. (1905/1981). The stages of higher knowledge (GA 12) (L. Monges \& F. McKnight, Trans. 1967) (Original work published 1905) Spring Valley, NY: Anthroposophic Press. 
Steiner, R. (1909/1965). The education of the child in the light of anthroposophy (GA 34) (2nd ed.) (G. \& M. Adams, Trans.) (Original work published 1909). London: Rudolf Steiner Press.

Steiner, R. (1914/1973). The riddles of philosophy (GA 18) (4th ed.) (Original work published 1914). Spring Valley, NY: The Anthroposophic Press.

Steiner, R. (1926/1986). Speech and drama (GA 282) (M. Adams, Trans.) [19 Lectures, Dornach, Switzerland, Sept 5 to 23, 1924) (Original German work published 1926) Spring Valley, NY: Anthroposophic Press.

Steiner, R. (1928/1972). A modern art of education (GA 307) (3rd ed.) (J. Darrell \& G. Adams, Trans.) [14 Lectures, Ilkley, Yorkshire, Aug 5 to 17, 1923] (Original work published 1928). London: Rudolf Steiner Press.

Steiner, R. (1930/1983). Metamorphoses of the soul: Paths of experience: Vol. 1 (GA 58) (2nd ed.) (C. Davy \& C. von Arnim, Trans.) [9 Lectures, Berlin and Munich, March 14 to December 9, 1909] (Original work published 1930). London: Rudolf Steiner Press

Steiner, R. (1931/1984). Eurythmy as visible speech (GA 279) (Rev. ed.) (V. \& J. ComptonBurnett, Trans.) [15 Lectures, Dornach, Switzerland, June 24 to July 12, 1924] (Original work published 1931) London: Rudolf Steiner Press.

Steiner, R. (1967). The younger generation: Education and spiritual impulses in the 20th century (Lectures, 1922). New York: Anthroposophic Press.

Steiner, R. (1970). The case for anthroposophy (GA 21) (3rd ed.) (O. Barfield, Trans.) (Extracts from Von Seelenratseln: Riddles of the soul, 1917) London, UK: Rudolf Steiner Press.

Steiner, R. (1982). Meditatively acquired knowledge of man (GA 302a) (T. van Vliet \& P. Wehrle, Trans.) [4 Lectures, Stuttgart, Germany, Sept 15 to 22, 1920] Forest Row, E. Sussex, U. K.: Steiner School Fellowship Publications.

Steiner, R. (1984). The realm of language and the lost unison between speaking and thinking (GA 162) (Rev. ed.) (G. Karnow \& A. Wulsin, Trans.) [2 Lectures, Dornach, Switzerland, July 17 \& 18, 1915] Spring Valley, NY: Mercury Press.

Sternberg, R., J. (1990). Wisdom: Its nature, origins and development. New York: Cambridge Unversity Press.

Sternberg, R., J. (1998). A balance theory of wisdom. Review of General Psychology, 2(4), 347365.

Sternberg, R., J. (2001). Why schools should teach for wisdom: The balance theory of wisdom in educational settings. Educational psychologist, 36(4), 227-245.

Sternberg, R., J. (2005). Older but not wiser? The relationship between age and wisdom. Ageing International, 30(1, Winter), 5-26.

Subbiondo, J. (2003). Lexicography and the evolution of consciousness: A study of Owen Barfield's History in English words. Historiographia Linguistica 30, 407-427.

Subbiondo, J. (2005). An approach to integral education: A case for spirituality in higher education. ReVision, 28(2), 18-23.

Tacey, D. (2003). The spirituality revolution: The emergence of contemporary spirituality. Sydney: Harper Collins.

Takaya, K. (2003, July). Education and imagination in historical context. Paper presented at the 1st International Conference on Imagination and Education, Vancouver, BC Canada.

The Mother. (1955). On education: Essays on education and self-development, written between 1949 and 1955 Pondicherry: Sri Aurobindo Ashram Trust. 
Thompson, W. I. (1998). Coming into being: Artifacts and texts in the evolution of consciousness. London: MacMillan Press Ltd.

Uhrmacher, B. P. (1993). Making contact: An exploration of focused attention between teacher and students. Curriculum Inquiry 23(4), 433-444.

van Manen, M., \& Shuying, L. (2002). The pathic principle of pedagogical language. Teaching and Teacher Education, 18(2), 215-224.

Varela, F., Thompson, E., \& Rosch, E. (1993). The embodied mind: Cognitive science and human experience. Cambridge, Massachusetts: The MIT Press.

Visser, J. (2000). Rethinking learning: Implications for policy, research and practice. In M. Jain (Ed.), Unfolding learning societies: Challenges and opportunities. Udaipur: Shikshantar: The People's Institute for Rethinking Education and Development.

Warnock, M. (1976). Imagination. Berkeley, CA: University of California Press.

Whitehead, A. N. (1916/1967). The aims of education. New York: Free Press.

Whitehead, A. N. (1919). Discussion upon fundamental principles of education. Process Studies, 14(1), 41-43.

Whitehead, A. N. (1925). Science and the modern world. Cambridge: Cambridge University Press.

Whitehead, A. N. (1929/1985). Process and reality. New York: Free Press.

Wilber, K. (2000a). A theory of everything: An integral vision for business, politics, science and spirituality. Boulder: Shambhala.

Wilber, K. (2000b). Integral psychology: Consciousness, spirit, psychology, therapy. Boston: Shambhala.

Wilber, K. (2001). The eye of spirit: An integral vision for a world gone slightly mad. Boston: Shambhala.

Wilber, K. (2004). Introduction to integral theory and practice: IOS basic and the AQAL map. 2004, from http://www.integralnaked.org

Wilber, K. (2006). Integral spirituality: A startling new role for religion in the modern and postmodern world. Boston, MA: Shambhala Publications.

Willis, P. (2004). From "the things themselves" to a "feeling of understanding": Finding different voices in phenomenological research. Indo-Pacific Journal of Phenomenology, 4(1), 113.

Wittgenstein, L. (1968). Philosophical investigations. Oxford: Basil Blackwell's.

Woods, G., O'Neill, M., \& Woods, P. A. (1997). Spiritual values in education: Lessons from Steiner. The International Journal of Children's Spirituality, 2(2), 25-40.

Woods, P. A., \& Woods, G. (2002). Policy on school diversity: Taking an existential turn in the pursuit of valued learning? British Journal of Educational Studies, 50(2), 254-278.

Zajonc, A. (2006). Cognitive-affective connections in teaching and learning: The relationship between love and knowledge. Journal of Cognitive Affective Learning, 3(1), 1-9.

\footnotetext{
${ }^{1}$ Reductionism in science is the process which involves "starting from wholes and moving "down" into parts, [in which] one is moving in the opposite direction from the way matters arise" (Goodenough \& Deacon, 2006, p. 853).

${ }^{2}$ The term spiritual is used here to denote ways of thinking not limited by scientific materialism, but which acknowledge there is more to life than matter, without necessarily subscribing to a particular religion.
} 
${ }^{3}$ Although this quote is well known, oft-cited, and always attributed to Einstein, I have not been able-in spite of numerous searches - to uncover its source.

${ }^{4}$ Holism has often been taken as the thesis that the whole is more than the sum of its parts.

http://plato.stanford.edu/cgi-bin/encyclopedia/archinfo.cgi Holistic/integral/unitive consciousness is identified as a feature of postformal thinking (Gidley, 2006, 2007a, 2007b).

${ }^{5}$ Construct-aware is a term used by Cook-Greuter (2000) to refer to the ability to become aware of one's language habits and to consciously move beyond them so that we are self-reflexively conscious of our own language. I introduce the term language reflexivity as an alternative to construct awareness, with similar intent.

${ }^{6}$ The university template is different as its genealogy is arguably more connected to the monastery template.

${ }^{7}$ Even within theoretical frameworks that purport to be the most holistic or the most integral, there can be a shadow of competitiveness or even elitism, where proponents of one version either undermine or don't adequately reference others of slightly different persuasion. My interest is integration of integral and other postformal and planetary approaches to begin philosophical coherence. My approach reflects on itself, and includes the particularities of other integral approaches - not to imply either a competitive, hierarchical, one-upmanship, or a horizontal relativism.

${ }^{8}$ Sri Aurobindo's spiritual philosophy was pedagogically developed through his spiritual collaborator, The Mother.

${ }^{9}$ I am not sufficiently informed to comment on the trends in European and other non-Anglo nations, except that in the so-called developing world, there is a strong, modernist, political and economic movement to transplant the formal factory-model of schooling into these diverse cultures. There is also a postcolonial critique of this neo-colonialist agenda (Gidley, 2001; Inayatullah, 2002; Jain \& Jain, 2003; Jain, Miller, \& Jain, 2001; Visser, 2000).

${ }^{10}$ I use postformal to refer to the pedagogical approaches pointing beyond the factory model of formal education.

${ }^{11}$ I coin the term delicate theorising in reference to Goethe's delicate empiricism (Holdrege, 2005;

Robbins, 2006).

${ }^{12}$ Contemplative studies programs have been developed at Brown University http://www.brown.edu/Faculty/Contemplative Studies_Initiative/courses.html

and The Center for Contemplative Mind in Society http://www.contemplativemind.org/about/history.html

${ }^{13}$ See for example the Global Dialogue Institute http://global-dialogue.com/

${ }^{14}$ I acknowledge that I came across this quote from Wittgenstein in the book To Dwell with a Boundless Heart: Essays in Curriculum Theory, Hermeneutics, and the Ecological Imagination (Jardine, 1998, p. 25).

${ }^{15}$ Foucault (2005) pointed out that self-care was part of the spiritual path to knowledge for approximately two millennia until the Cartesian split of spirituality and philosophy.

${ }^{16}$ Most Steiner schools do not encourage teachers to use textbooks, but rather to research and individualise the content aspect of lessons through their own imagination and creativity.

${ }^{17}$ Although not strongly emphasised in the postformal adult development literature, imagination is linked with postformal development by some researchers (Bassett, 2005b; Cook-Greuter, 2000; Sinnott, 2005).

${ }^{18}$ The term imaginal thinking was used by Steiner in 1917 to represent a conscious activation of a higher faculty of imagination conjointly with the concept-forming thinking mind to create living concepts. "I have applied the term 'imaginal' to representations that are apprehended by the psyche as living" (Steiner, 1970, p. 39). The term imaginal has re-emerged in contemporary educational writing, based on the work of Jungian psychologist James Hillman and others. It is referred to as a "pre-analytical mode of knowing and being" (Willis, 2004, p. 8 of 13) in contrast with Steiner's post-rational intent. 
${ }^{19}$ The term training in educational settings is a behaviourist metaphor. Although it has been used in an integral education context to distinguish three elements of an integral curriculum: "content, training and inquiry" (Ferrer, Romero, \& Albareda, 2005, p. 307-308), my preference is for non-behaviourist terms.

${ }^{20}$ Kieran Egan's Imaginative Education Research Group based in Vancouver has created a community of scholars, educators and researchers focusing on this vital aspect of educational transformation.

www.ierg.net

${ }^{21}$ Functional illiteracy refers to being able to read the words in a text but not understand the meaning and/or be able to apply it to everyday life. According to a support group for literacy in Tucson, Arizona, "In the U.S.A. 40-44 million (21-23\% of adults) are functionally illiterate. Among young adults, illiteracy is increasing." http://www.lovetoread.org/dev/literacy.html Further research is needed to establish the veracity of this claim.

${ }^{22}$ Sternberg's balance theory is a complex theory and it is beyond the scope of this paper to elaborate.

${ }^{23}$ This echoes Pestalozzi‘s and Steiner's emphasis on balancing head, heart and hands in education.

${ }^{24}$ There are emergent global initiatives directed towards wisdom, such as the World Wisdom Council http://www.wisdompage.com/worldwisdomcouncil.html and the Wisdom Institute http://www.wisdominst.org/wisdom.htm

${ }^{25}$ I have gratefully borrowed and adapted this phrase from the book Creativity across domains: Faces of the muse (Kaufman \& Baer, 2005).

${ }^{26}$ These terms were taken from notes I took at a conference presentation (MacLure, 2006c).

${ }^{27}$ Family resemblances was used by Wittgenstein (1968) to refer to the "complicated network of similarities, overlapping and criss-crossing" found in different word uses and meanings (p. 32).

${ }^{28}$ The term nanotextology was playfully utilised to refer to construct-awareness of each word (Hampson, 2007).

${ }^{29}$ The term eurythmy means beautiful or harmonious rhythm from Greek roots eu- "well" + rhythmos "rhythm." http://www.etymonline.com/index.php?term=eurythmic Eurythmy brings together "form, movement and language [which] all sound the essential nature of the world in different ways." http://eurythmy.org/abeurp1.html

${ }^{30}$ The Centre for Children and Young People (CCYP) at Southern Cross University, where I am undertaking this research, emphasises children's voices as a significant component of its mission, through the participation of children and young people in research (e.g. The Young People: Big Voice Project) http://ccyp.scu.edu.au/index.php

${ }^{31}$ The honouring of children's voices in education is in line with the UNESCO project Education for All through Voices of Children http://www.unesco.kz/education/efa/booklet voice.pdf

${ }^{32}$ Pedagogical language has been referred to as a pathic principle in learning, including "presence, relational perspectives, tact" referred to as "pre-reflective, pre-theoretic, pre-linguistic and non-cognitive" (van Manen \& Shuying, 2002). This is a complex area in which some researchers would call these postformal. 